\title{
Research on Elementary Mathematics Education Between China and Britain
}

\author{
Wenrui Xu \\ Kings Collage of London, London, the United Kingdom, Strand, London WC2R 2LS \\ Corresponding author. Email: k19029985@kcl.ac.uk
}

\begin{abstract}
In recent years, the trend of international education has been obviously developed and a great number of Chinese students choose to study abroad in different age. According to the report of PISA 2018, Chinese students got the highest score in reading, mathematics and science around the world. This study focuses on the comparison of Chinese and British mathematics education and find out the feasibility of interactive learning in primary mathematics education. Through reviewing the literature, British and Chinese different history cultures and education policy that may effect education differences are compared. All the information and data are collect from published articles. By analyzing the literature, it is found that the belief of Chinese teachers is quite different from British teachers. For Chinese teachers, they not only pay more attention to logical and rigorous reasoning than British teachers, but also agree that mathematics has a significant effect on other disciplines. Moreover, British mathematics teachers focus more on further mathematics education than Chinese teachers. This cultivates the ability of students to think independently.
\end{abstract}

Keywords: History, comparison, Britain, China, method

\section{INTRODUCTION}

On the basis of the statistics of United Nation Educational, Scientific and Cultural Organization, China has become the largest country that send more than 900,000 international students to different foreign countries during nearly two decades[14]. Based on this result, this phenomenon has had a great positive impact and promotion on the global education.

According to the PISA 2018 results, the mean score for mathematics and science was 489 points. Especially in Beijing, Shanghai, Jiangsu and Zhejiang(China), the highest mean score(591 points in mathematics and 590 points in science) among the world was achieved and it was extremely higher than the world average[16]. Compare to the United Kingdom, it had a mean score 502 in mathematics and 505 in science which had approximately 80 points lower than that in China[15]. Based on these results, readers can simply find that Chinese students have better learning ability in mathematics and science than students in other countries, and the overall scores of Asian students are higher than that of other regions.
The purpose of the study is to discuss the feasibility of interactive learning in primary mathematics education in China and England under the influence of globalization. This study will compare the different education policy and teaching method in China and England by literature review. The significance of this study is to learn from each other's strengths and make up for their weaknesses between Chinese and Western mathematics education, it is an opportunity to achieve educational diversification around the world.

\section{CHINESE EDUCATION SYSTEM: ANCIENT AND MODERN}

In ancient China, there was a formal education system nearly two thousand years ago and it is also the oldest education system in the world. The formation of the imperial examination system(keju) is based on the meritocratic ideals that still implement to this day in China. With the development of education for thousands of years, people find that this type of examination is the most fair and efficient way to identify students' academic ability[5]. In ancient China, only the rich family's boys who are old enough are allowed to study, however, girls do not have any opportunity to study at 
all[7]. This phenomenon indicates that not everyone has the opportunity to receive education under many restrictions, and taking the imperial examination is the only way that people could change their lives in the ancient.

The earliest ruling dynasty of China was established in 1600 B.C and it was named by Shang, the Shang was leaded by a man named Tan. At that moment, mathematics and astronomy developed a lot. In 551 B.C, a person who can change the whole Chinese education system was born: Confucius - a teacher, politician and philosopher. The main ideal of Confucius was "Teaching for everyone, Teach students according to their aptitude", it means everyone no matter how rich or how poor can be educated, teachers should teach the students due to the actual situation and individual differences of students, so that every student can obtain the best development based on their strengths and they can avoid their weaknesses. This idea also became the central idea of Chinese education culture and was the foundation of modern schools. Until Qin Dynasty was established, the written scripts had been standardized[9].

Supported by Youwei Kang and Qichao Liang, the Emperor Xu Guang published a series policy to reform the Chinese education system in 1898. Based on these policies, a great number of population would have the opportunity to participate in modern education system. A brand new education policy was issued by Qing court during 1901 to 1905 , and in 1905, the imperial examination system(keju) was abolished, it means that it was the end of the Chinese traditional education system[6]. This was a major educational reform during the Chinese history and established the foundation of the modern educational system.

Since 1986, Chinese education system has three levels of education: basic education, higher education and adult education. Especially in basic education, it usually contain three years of preschool education, six years primary education and six years secondary education. In addition, every Chinese children must have Nine-Year compulsory education from primary school to the first three years of secondary school[8]. This policy means each Chinese children has the right to receive basic education.

Chinese children will learn the multiplication law and memorize how to calculate correctly in mind when they are in the very beginning of the primary education. According to the Chinese culture, children will be taught to follow the routine way, which is the most efficient to understand and solve different mathematics question. Chinese mathematics system is more likely to encourage children do some rigid practice to improve their conceptual knowledge. In the use of mathematics language, Chinese teacher are also very strict. The wrong use of mathematics language will cause student to lose many scores in the exams[12].
A traditional Chinese mathematics teacher in a primary school will only focus on math subject for two classes every day. This teaching method will enable the teacher to understand the student's acceptance of mathematics knowledge in each class. Teachers in different areas in a city will select the most excellent mathematics teaching classroom in a fixed period time. In order to urge teachers to carry out effective teaching method and improve teachers' teaching level. The selection of excellent teachers can also make teachers be more motivated in their future teaching career[12]. Thus, it may cause a phenomenon that when the teachers in some areas do not have such strong teaching ability, the academic ability of students who are in these areas may have a great gap than the other areas that have a strong teaching ability.

\section{EDUCATION HISTORY AND TEACHING METHOD IN ENGLAND}

In 597, St Augustine was earned the honor by establishing the education system and two types of school which were grammar schools for Latin and song schools. At that moment, education was only served for nobles. Until 1150, there existed free grammar schools which were not controlled by church and could teach any other subjects. Since National Society was established, the purpose of Society to build the schools which were located near the churches was charitable and the major was about religion education. They proved education opportunity for poor and these basis courses increase the rate of elementary education, although the the average attendance was only one year[17]. Since 1870 , it was the first time that government established the policy of elementary education for children who aged from 5 to 13. Based on Taunton(1868), the course only focused on reading, writing and arithmetic. The education bureau was responsible for collecting taxes and running schools. The school funds were borne by the state, local taxes and students' parents. Students from poor families could be exempted from paying tuition fees[17]. The Churchill government promulgated the Butler act(1944). The main content was to strengthen the national leadership over education and found the connection between primary education and secondary education[19]. Based on the Act, the society set elementary schools which offered children who aged from 5 to 11 and secondary schools which offered children who aged from 11 to 15 . And all the children were free to get education. The schools not only provided academic education, but also established Health serves which in order to required meals, free milk medical and dental cares[17].

According to the research which was written by Anna Riggall and Caroline Sharp(2008), there exists five stages of education in the current UK: early years, primary education, secondary education, further 
education and higher education. Especially in primary education, UK policy divides primary school into three categories such as Community schools, Voluntary schools and Foundation schools, each of them are established by LAs and churches respectively[1]. Every student in UK has compulsory education from the age of 5 (or 4 in the Northern Ireland) to 16. The main purpose for primary school student is to establish the basic perception of science, mathematics and other subjects. Every students need to learn the foundation in numeracy and literacy during their primary education years[2]. After hundreds of years of education's development, the main aim for UK education is to encourage students to think independently and confidently. According to the British tradition, it has pioneering approaches to teaching[3]. The study shows that based on different teaching method such as discussion, games, computer simulations. These methods are effective and the rate of drop-out is the lowest around the world[19].

According to the British education system, during the elementary education years, only one teacher is in charge of the study of a whole class for that year and this is the notable feature in the British education system. This teacher will continuously educate this class and expert teachers who are in some specific disciplines will also provide professional advance to the teacher[13]. With the development of society, the British education system has undergone several significant reforms during the hundreds of years. In particular, setting up different types of schools to help all children go to school. Personalized teaching methods enable students to learn the ability of independent thinking at the stage of primary education and reduce the rate of students' drop out.

\section{MATHS EDUCATION DIFFERENCES BETWEEN CHINA AND UK}

\subsection{The difference in teacher-student relations between China and UK}

The relationship between Chinese teachers and students is quite different from that of British. Chinese teachers are usually strictly in the class and students need to respect the teachers. The teachers and students are more like parents and children in class. They will be completely different after class. Chinese teachers are willing to spend time on communicating with students and want to find out what they think after class[21].

However, the relationship are more equal in British schools, British teacher are willing to be a friend with their students and the main teaching approach for them is more personal. In addition, British teachers hope to study and work with their classmates together[21].

According to the Xinhuanet.com, it reported in 2018 that the former British Prime Minister Teresa May visited China and proposed a total value of 550 million pounds into China and British cooperation in mathematics education, she hoped that this cooperation will continue until 2020 for improving the ability of students' mathematics. Based on the program which started from 2014, British students began to understand and come into contact with the Chinese decimal system, it will make students memorize $9 \times 9$ multiplication table more easily and this is the foundation for students to learn mathematics[11].

Based on Wenping Zhang and David Wray study, they compare the Chinese and British classroom. They used classroom observation and individual interview method. Zhang and Wray chose four secondary schools which are from Beijing, Shanghai in China and Coventry, Birmingham in UK. The aim for classroom observation was to figure out the questioning strategies that teachers might focus on. The individual interview was to enrich the details of classroom observation. Zhang and Wray found that the distinct difference between two countries classroom was that the number of students was asked the same question. The questioning pattern for Chinese teachers was collecting answers from different students. In order to finished the course in limit time, Chinese teachers prefer asking the same question to different students, therefore teachers who can make sure that most students understand the lesson and that the class can be continued. However, for British teachers, they are more likely to involve different individual problems for each student. British teachers believed that every students had different capacity for mathematics ability and students should learn knowledge based on their own abilities, therefore individual questioning was the best method to help students progress. When British teachers asked a question for a student, teachers would keep eye contact until they finished all questions[20].

\subsection{The difference of maths belief between China and $U K$}

In mathematics belief, Huiying $\mathrm{Yu}$, a student study in Faculty of Education from University of Cambridge finds that Chinese teachers not only pay more attention to logical and rigorous reasoning than British teacher, but also agree that mathematics has a strong influence in other disciplines. Yu thinks it may means that British mathematics teacher will focus more on mathematics education than Chinese mathematics teachers. In order to reach this conclusion, $\mathrm{Yu}$ uses a questionnaire and follow-up interview for both British mathematics teachers and Chinese mathematics teachers from Shanghai secondary school. The most important finding of Yu's report is that there are existing differences in belief of mathematics between British and Chinese teachers. For British teachers, they usually use the pragmatic understanding of theory to relate the 
mathematics, and for Chinese teachers, they prefer to use the scientific understanding of theory to relate. In addition, Chinese teacher will focus more on the new method to prof and the role of precise mathematics language. $\mathrm{Yu}$ indicates that science and mathematics are the most popular subjects for the Chinese students, most of them will choose these subjects in higher education. Chinese students think that science will have a positive effect to their future research. However, British students are completely opposite to Chinese students. Most of them prefer to choose liberal arts as their future learning goal[10].

Debbie Morgan is a director for Britain's National Central for Excellence in the Teaching of Mathematics(NCETM) for primary school, he finds that for Shanghai(China) primary schools, the main mathematics belief is that if students can be taught well, then they can do well. A past research by Shefield Hallam University found that the score of British students who use the mathematics method of Shanghai was above the national average between 2015 to 2017 . Carol Knights is a director for secondary school at NCETM, he suggested that students need to understand the concepts from simple to difficult, therefore confidence can be built during the process of studying. This is also the main mathematics belief for Shanghai teachers. Knights believed that the mathematics method of Shanghai is not magic, the most important part for most Chinese students is 'mastery'[4].

\section{CONCLUSION}

For Chinese education system, most teachers will prefer to tell all the known mathematics contents to their students, ask them to memorize. Then teachers will assign a large number of similar questions which is based on these contents to practice. This kind of teaching method may increase the efficiency and accuracy of problem solving. However, it may also lead to a lack of independent thinking for students. For British, the number of students in each class will be controlled in a small range. Under this condition British teachers can conduct classroom interaction and guidance based on the situation of different students. Although some of British students may not really good at basic mathematics, they can bring full play to their potential.

In general, interactive learning in China and Britain is feasible. Chinese modern education will extract the excellent core concepts from the western education and apply them to the lessons. What is more, basic mathematics of Chinese education also provide effective help for Britain education, multiplication table will improve the ability of British students calculation.

However, this research is mainly based on literature review, it is lack of data analysis and a large number of questionnaire interview. Therefore, the data is relatively inaccurate. Moreover, different cities in one country may have different education policy. So there exists uncertainty of policy in each region. The further study will set a large number of questionnaire interview and data collection from different areas in each country.

\section{REFERENCES}

[1] Anna Riggall and Caroline Sharp. 2008. National Foundation for Education Research. The Structure of Primary Education: England and Other Countries. [ONLINE] Available at: https://www.nfer.ac.uk/publications/pro01/pro01.p df.

[2] assets.publishing.service.gov.uk. [ONLINE] Available at: https://assets.publishing.service.gov.uk/government /uploads/system/uploads/attachment_data/file/2191 67/v01-2012ukes.pdf.

[3] British Council. 2021. [ONLINE] Available at: https://www.britishcouncil.id/en/study-uk/why/ourteaching-methods.

[4] Cecily Liu. 2019. UK Teachers find Shanghai math adds up. Chinadaily.com. [ONLINE] Available at: http://www.chinadaily.com.cn/a/201901/28/WS5c4 e5bf2a3106c65c34e6c24.html.

[5] Chelsea Shieh. China's Education System: The Oldest in the World. China Learning Initiatives [ONLINE] Available at: https://asiasociety.org/china-learning-initiatives/chi nas-education-system-oldest-world.

[6] China -History Background. [ONLINE] Available at: https://education.stateuniversity.com/pages/269/Ch ina-HISTORY-BACKGROUND.html.

[7] Diane Sieverson. 2021. Education in Ancient China: Lesson for Kids. Study.com [ONLINE] Available at:

https://study.com/academy/lesson/education-in-anc ient-china-lesson-for-kids.html.

[8] Dr Qian Kan. 2019. A brief introduction to the Chinese education system. OpenLearn. Open University. [ONLINE] Available at: https://www.open.edu/openlearn/education/brief-in troduction-the-chinese-education-system.

[9] HISTORY. 2019. China: Timeline. HISTORY. [ONLINE] Available at: https://www.history.com/topics/china/china-timelin e.

[10] Huiying Yu. 2008. A comparison of mathematics teachers' beliefs between England and China. In Joubert, M. (Ed.) Proceedings of the British Society for Research into Learning Mathematics 
28(2). [ONLINE] Available at: http://www.bsrlm.org.uk/wp-content/uploads/2016/ 02/BSRLM-IP-28-2-21.pdf.

[11] Hongyu and Bianji. 2018. UK continues to expand cooperation with China in math education. People's Daily Online. [ONLINE] Available at: http://en.people.cn/n3/2018/0301/c90000-9431565. html.

[12] Kan Wei. 2014. Explainer: What makes Chinese maths lessons so good?. [ONLINE] Available at: https://theconversation.com/explainer-what-makeschinese-maths-lessons-so-good-24380.

[13] L R Hand. The British Education System. British Culture, Customs and Traditions. [ONLINE] Available at: https://www.learnenglish.de/culture/educationcultu re.html.

[14] Mini Gu, Rachel Michael, Claire Zheng and Stefan Trines. 2019. Education in China. World Education News + Reviews. [ONLINE] Available at: https://wenr.wes.org/2019/12/education-in-china-3.

[15] PISA 2018 Results: Combined executive summaries. 2019. [ONLINE] Available at: https://www.oecd.org/pisa/Combined_Executive_S ummaries_PISA_2018.pdf.

[16] PISA 2018 Results (Volume I). OECD iLibrary. [ONLINE] Available at: https://www.oecd-ilibrary.org/sites/28450521-en/in dex.html?itemId=/content/component/28450521-en

[17] Schoolsmith. 2019. A short history of education in England. Schoolsmith [ONLINE] Available at: https://www.schoolsmith.co.uk/history-of-educatio $\mathrm{n} /$.

[18] Teaching methods in UK. GeeBee Education. [ONLINE] Available at: https://www.geebeeworld.com/Country-of-Study/u nited-kingdom/education-system/teaching-methods /.

[19] The Butler Act. The Cabinet paper. A The National Archives. [ONLINE] Available at: https://www.nationalarchives.gov.uk/cabinetpapers /themes/butler-act.htm.

[20] Wenping Zhang, David wray. 2019. A cross-cultural comparative study into teachers' questioning patterns in lower secondary mathematics lessons in the UK and China. HAL|archives-ouvertes.fr. [ONLINE] Available at: https://hal.archives-ouvertes.fr/hal-02421824/docu ment.
[21] Yiyi Miao. 2016. A Study of the Differences Between China and UK Classroom Teaching in Middle Schools Based on a BBC Documentary. Sino-US English Teaching, November 2016, Vol. 13, No. 11, 856-859. [ONLINE] Available at: http://www.davidpublisher.com/Public/uploads/Co ntribute/582a6d49d1cef.pdf. 